УДК 780.06(091)

ББК 85.315-03

DOI 10.25281/2072-3156-2018-15-1-58-65

\title{
А.В. УСТЮГОВА
}

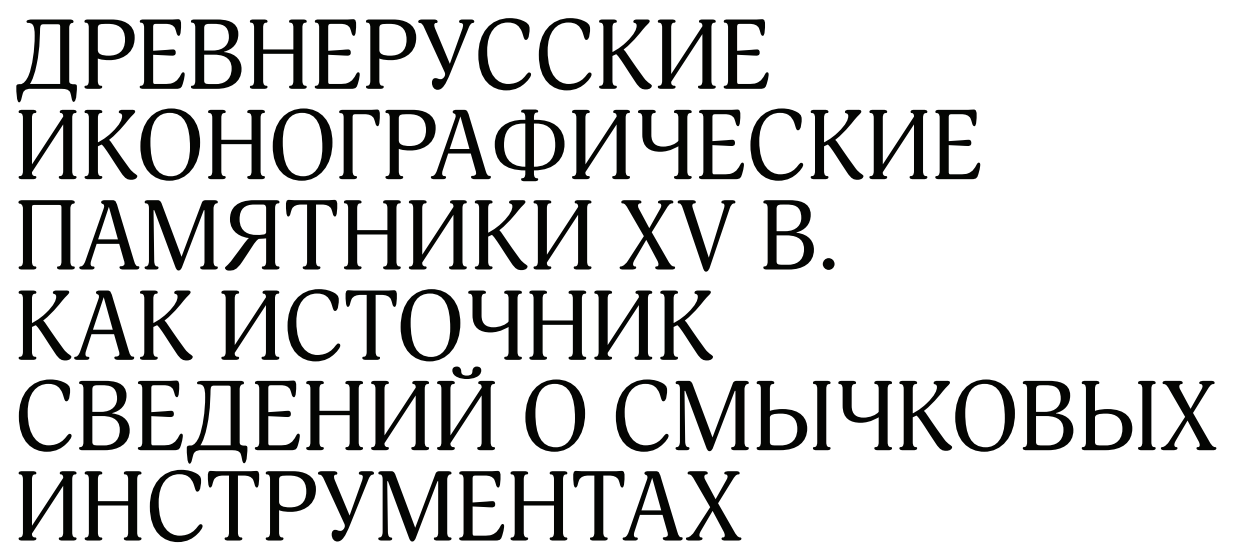

Александра Викторовна Устюгова,

Красноярский педагогический колледж № 1

им. М. Горького,

музыкальное отделение,

преподаватель теоретических дисциплин

Урицкого ул., д. 106, Красноярск, 660049, Россия

кандидат искусствоведения

E-mail: uav80@mail.ru

Реферат. Древнерусские изобразительные источники дают иенный историко-бытовой материал, способствующий уточнению наших представлений об особенностях конструкции и функиионирования музыкальных инструментов. Среди дошедших до нашего времени сведений о древнерусских смычковых инструментах особую значимость приобретают фрески и миниатюры рукописных книг.

В статье рассматриваются смычковые инструменты на фреске «Ант Скоморох» западной стены Успенской иеркви близ села Мелётово Псковской области (1465) и миниатюре «Царь Давид беседует с певцами» из первой части Следованной Псалтири (1470-1480). Исследуемые иконографические источники содержат не только изображения смычковых инструментов, но и надписи, вследствие чего возрастает их значимость для изучения древнерусской инструментальной культуры.

Впервые предпринята попытка комплексного анализа смычковых инструментов в древнерусском изобразительном искусстве XV в. в сопоставлении со средневековыми западноевропейскими и византийскими иллюстрациями, а также древнерусски- ми письменными и археологическими материалами. Методологическую основу исследования составляют сравнительно-типологический и исторический подходы, позволяюшие выделить и соотнести основные типы средневековых смычковых инструментов, их сходство по форме и исполнительским приемам.

В результате сравнительно-типологического анализа древнерусских иконографических памятников XV в. делается вывод о том, что изображения смычковых инструментов представляют некоторый переходный образеи - ещуе не отошли от византийского влияния, содержат признаки западноевропейского инструментария, но уже вбирают специфические национальные древнерусские черты. В XV в. на древнерусских миниатюрах и фресках появляются надписи, поясняющие, что на них народные музыканты. В этот же период впервые в древнерусском искусстве воссоздается вертикальное игровое расположение инструмента, что соответствует русской традиици исполнительства на смычковых инструментах. Ряд конструктивных особенностей сближает изображенные инструменты с гудками XII-XV вв. Новгородской археологической экспедиции (форма корпуса, головки, отсутствие продолженного грифа, наличие трех струн и лукообразный смычок).

Ключевые слова: древнерусское изобразительное искусство, русская инструментальная музыка XV в., смычковые инструменты, гудки.

Для цитирования: Устюгова A.B. Древнерусские иконографические памятники XV в. как источник сведений о смычковых инструментах // Обсерватория культуры. 2018. Т. 15, № 1. C. 58-65. DOI: $10.25281 / 2072-3156-2018-15-1-58-65$. 


\section{$\prod_{1}$}

ревнерусские рукописные книжные миниатюры и фрески XV в. содержат изображения смычковых инструментов, которые проявляются в индивидуализированных образах. Иконографические источники позволяют познать разнообразие древнерусского инструментария, расширить наши представления о внешнем строении средневековых музыкальных инструментов и особенностях исполнительства.

В статье мы рассмотрим памятники древнерусского искусства конца XV в., воссоздающие смычковые инструменты, - фреску «Ант Скоморох» западной стены Успенской церкви близ с. Мелётово Псковской области (1465) [1, с. 17] и миниатюру «Царь Давид беседует с певцами» из первой части Следованной Псалтири (1470-1480) [2, с. 166]. Несмотря на то, что оба изображения созданы практически в одно время, на территориях, не очень далеко расположенных друг от друга (Псковская и Вологодская области), они воссоздают два принципиально различных смычковых инструмента. Расхождение их заключается не только в форме инструмента, но, что немаловажно, и в способе игры на нем.

В работе использован сравнительно-типологический анализ. Исследуемые изображения соотнесены со средневековыми византийскими и западноевропейскими иллюстрациями смычкового инструментария, а также письменными источниками XVIIXIX вв. и археологическими находками, датируемыми XII-XV веками.

Рукопись Следованной Псалтири содержит две части, написанные в разных местах. Первая часть рукописи была создана в $1470-$ 1480 гг. в Кирилло-Белозерском монастыре (Вологодская обл.), вторая часть, относящаяся к более позднему времени - 1510 1520-м гг., происходит из Троице-Сергиева монастыря.

Миниатюра «Царь Давид беседует с певцами» из первой части рукописи размещена, наряду с другими изображениями, до текста Псалтири в качестве иллюстрированного предисловия «Сказания о Царе Давиде» (см. рис. 1). Эта миниатюра до сих пор не исследована специалистами-инструментоведами, тем не менее она является ценным историческим свидетельством о смычковых инструментах конца XV века.

Основным повествованием при воспроизведении смычковых инструментов на

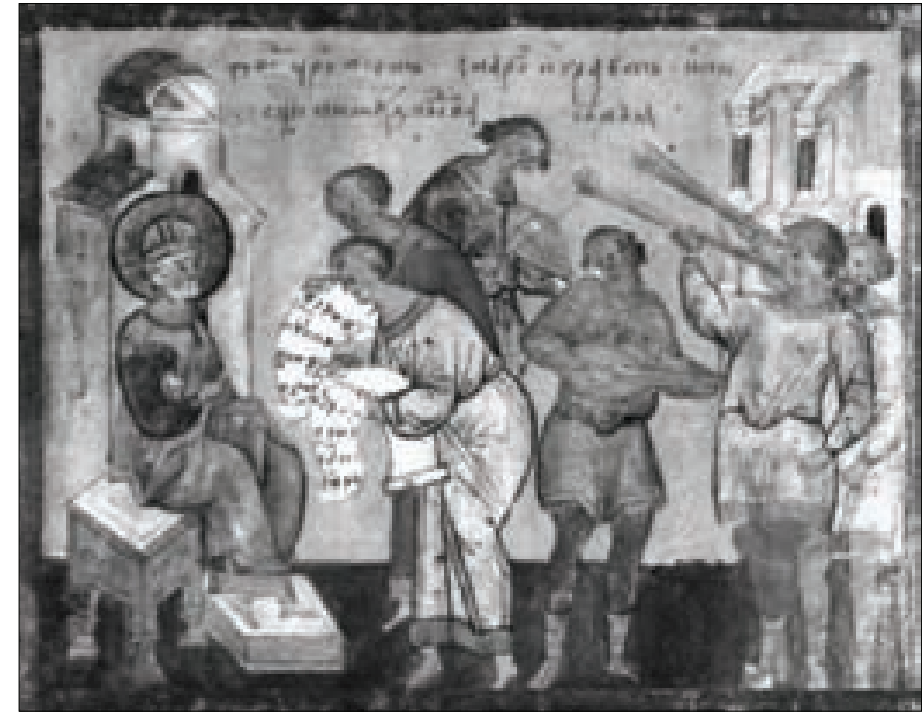

Рис. 1. Миниатюра «Царь Давид беседует с певцами» из первой части Следованной Псалтири 1470-1480 гг. [2, с. 166]

древнерусских книжных миниатюрах становится библейское сказание о Царе Давиде. В верхней половине иллюстрации имеется надпись: «Давид царь поет, и народ гудеть, и писцы пишут Давидова пения» [2, с. 166]. Миниатюра изображает Царя Давида в окружении четырех музыкантов, играющих на различных инструментах, в том числе струнном смычковом. Одеяния их выдержаны в одном стиле и представляют тип древнерусского крестьянского костюма с характерными национальными чертами: рубаха навыпуск, подпоясанная цветным шнуром, и узкие штаны, заправленные в сапоги [3, с. 89-90]. Головных уборов на музыкантах нет.

Это одно из последних изображений в древнерусском искусстве, на котором запечатлен горизонтальный способ держания смычковых инструментов, с XVI в. основным становится воссоздание вертикального игрового положения независимо от размера ${ }^{1}$. Письменные источники также фиксируют вертикальную манеру игры на народном смычковом инструменте - гудке. Наиболее ранние и подробные сведения об особенностях исполнительства на гудке в XVIII в. сообщил Я. Штелин, отмечавший, что «играют на нем либо сидя, упирая его в колени, либо стоя, упирая в корпус, а, в общем, не как на скрипке, прижимаемой к груди или подбородком» $[4$, с. 66].

В отличие от более ранних изображений музыкантов со смычковыми инструментами в сидячем положении с ногами, скрещенными в позе лотоса (фреска Софийского собоpa XI в. и Хлудовская Псалтирь XIII в.), на данной миниатюре фигура игрока запечатлена стоя. Во всем его облике,

\footnotetext{
${ }^{1}$ Вертикальное игровое положение при изображении смычковых инструментов представлено на миниатюрах из Годуновских Псалтирей Ипатьевского монастыря $(1591,1594)$, Чудовской Псалтири следованной (1556-1566), Лицевой Псалтыри (1558-1573), Псалтыри толковой Ипатьевского монастыря (1654), Апокалипсиса (1650-1680-е), рукописного Синодика (XVII в.) и др.
} 


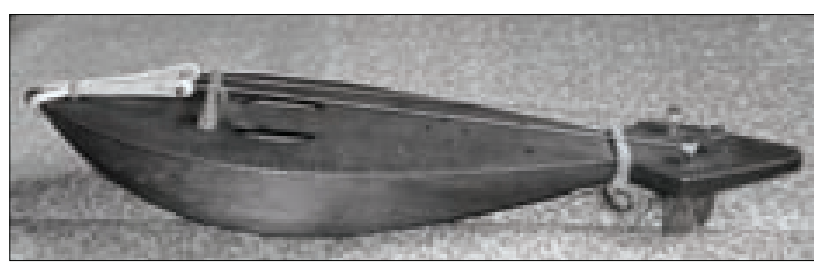

Рис. 2. Реконструкция гудка археологических раскопок В.И. Поветкина

пластике передано ощущение игрового движения. Музыкант упирает инструмент в плечо и немного наклоняется в его сторону.

Корпус смычкового инструмента грушевидного вида переходит в основание шейки, продолжение которой, как и головки, не видно, поскольку они скрыты фигурой музыканта, играющего на струнном щипковом инструменте ${ }^{2}$. Количество струн сложно распознать, но их не меньше трех. В правой руке у музыканта - короткий лукообразный смычок, он держит его в нижней части «боковым» способом, заключающимся в расположении кисти играющего сбоку или снизу колодки.

Изящно прорисованные грушевидные формы смычкового инструмента на миниатюре, лукообразный смычок, наличие трех струн сближают его с гудками XII-XV вв. Новгородской археологической экспедиции ${ }^{3}$ (см. рис. 2) и описаниями гудка в литературе XVII-XVIII веков.

В исследовании Д. Мунроу есть фотография трехструнной турецкой смычковой лиры из частной коллекции (см. рис. 3) [5]. Конструкция ее в точности совпадает с гудками Новгородской археологической экспедиции и похожа на изображение смычкового инструмента из Следованной Псалтири. Турецкая смычковая лира восходит к византийской лире, на ней играют на всех прежних территориях Византийской империи, в том числе в Турции. Специального исследования требует вопрос: были ли завезены смычковые византийские лиры в Новгород из Византии и местные мастера переняли способ их изготовления или же они являются продуктом исконно русским?

Кирилло-Белозерский монастырь, где была написана миниатюра, расположен на северо-запа-

2 По форме этот инструмент близок смычковому, но отличается более крупными размерами и длинной тонкой шейкой.

3 Первые открытия в Великом Новгороде смычковых инструментов и их деталей XI-XV вв. относятся к 1954 году. Научный анализ и их идентификацию провел Б.А. Колчин в конце 1960-х годов. Ученый полагал, что найденные музыкальные инструменты и их детали представляют собой древнерусский смычковый инструмент гудок. В настоящей статье мы пользуемся определением Б.А. Колчина в отношении смычковых инструментов из Новгородских и Псковских археологических раскопок. Автор выражает благодарность Н.Н. Поповой, директору новгородского Центра музыкальных древностей им. В.И. Поветкина за предоставленные материалы. де России, там же при археологических раскопках были найдены гудки, художник вполне мог видеть подобные инструменты в музыкальном быту. Надпись в верхней части миниатюры - «народ гудеть» указывает на то, что перед нами музыкант из народа, что соответствует и его внешнему облику с элементами древнерусского мужского костюма. Можно было бы с уверенностью классифицировать исследуемый образец как гудок, но на изображении из Следованной Псалтири инструмент держится в горизонтальном положении, что не свойственно гудку и русской традиции исполнительства на нем.

Музыкальные инструменты (две трубы и лютня), составляющие ансамбль со смычковым, также не вносят ясности в вопрос идентификации, поскольку они были в употреблении и в Византии, и в Западной Европе, и в Древней Руси XV века.

На византийских иллюстрациях из рукописных книг основным является изображение игры на смычковых инструментах посредством удержания на плече - «а браччо», для них также характерна «боковая» манера держания смычка, что мы видим и на миниатюре из Следованной Псалтири. В то же время, как отмечено выше, рассматриваемый нами смычковый инструмент в некоторых элементах схож с гудками XII-XV вв. Новгородской археологической экспедиции. Мы не можем достоверно утверждать, что подобных инструментов не существовало в музыкальной культуре Древней Руси, поскольку не имеем описаний смычковых инструментов обозначенного периода. Наиболее логичной все же представляется гипотеза заимствования византийской иконографической схемы при воссоздании данного смычкового инструмента. Древняя Русь восприняла от Византии

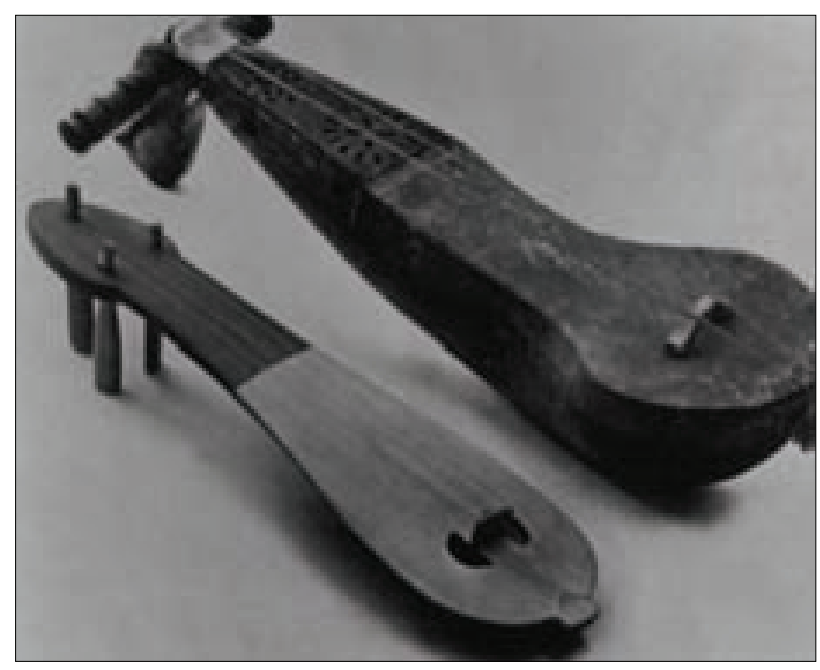

Рис. 3. Трехструнная турецкая лира и марокканский двухструнный ребаб из частной коллекции

(изображены в последовательности слева направо) [5, p. 27] 
церковный канон ${ }^{4}$, воплощавшийся, прежде всего, в сфере художественных образов. Обучение древнерусских мастеров происходило непосредственно от византийских художников, которые являлись также авторами росписей первых храмов и рукописных книг Древней Руси.

Музыкальный инструмент на фреске западной стены Успенской церкви близ села Мелётово Псковской области (росписи были завершены в 1465 г.) открывает серию иллюстраций с вертикальным держанием смычковых инструментов (см. рис. 4). Начиная с этой фрески, мы обнаруживаем на древнерусских миниатюрах изображение общей для всех смычковых инструментов манеры игры. Перед нами предстают различные формы инструментов и единственный элемент, который их сближает, - вертикальное положение инструмента «перед собой», иногда с упором в колено, независимо от того сидит или стоит музыкант.

Мелётовские фрески были открыты Н.К. Богушевским случайно в конце XIX в., осыпавшаяся со стен штукатурка обнажила фрагменты росписей [6]. В 1925-1926 гг. они были переоткрыты К.К. Романовым, после чего и началась работа над их реставрацией. Фреска с музыкантом, по определению Ю.Н. Дмитриева ${ }^{5}$, была расписана художником псковской школы живописи, на что указывают такие особенности, как плоскостность композиции, стремление к узорности в орнаментальном оформлении и «псковский» тип некоторых лиц [7, с. 408]. Роспись воспроизводит композицию, состоящую из двух частей и иллюстрирующую, как установил Д.С. Лихачев, сказание «О некоем скомрасе, хулившем пречистую богородицу» [8, с. 463]. Этот текст заимствован из византийского сборника «Лимонис» ${ }^{6}$, который был создан Иоанном Мосхом в VII веке. Сказание повествует о скоморохе, который высмеивал и ругал Богородицу. Она являлась к нему троекратно с просьбой прекратить сквернословие, но скоморох ее не послушал, и Богородица наказала его, лишив рук и ног. Возможно, фрески составляли цикл, изображающий повествование о Богоматери, из которого сохранилось лишь два эпизода: сцена с музыкантом и явление Богоматери. На сегодняшний день неизвестно других древнерусских иконографических памятников, в которых воссоздавался бы данный сюжет.

По мнению Ю.Н. Дмитриева, действо первой части фрески с музыкантом составляет бытовую сцену

\footnotetext{
${ }^{4}$ Свод церковных правил, установлений.

5 Ю.Н. Дмитриев в 1948-1949 гг. работал над реставрацией росписей, также им опубликовано исследование о Мелётовских фресках [7].

${ }^{6}$ Рассказ о Богородице и скоморохе из сборника «Лимонис» входит в состав Синайского патерика, сохранившегося в списке конца XI - начала XII в. (ГИМ, Синодальное собрание, № 551) [9, c. 488].
}

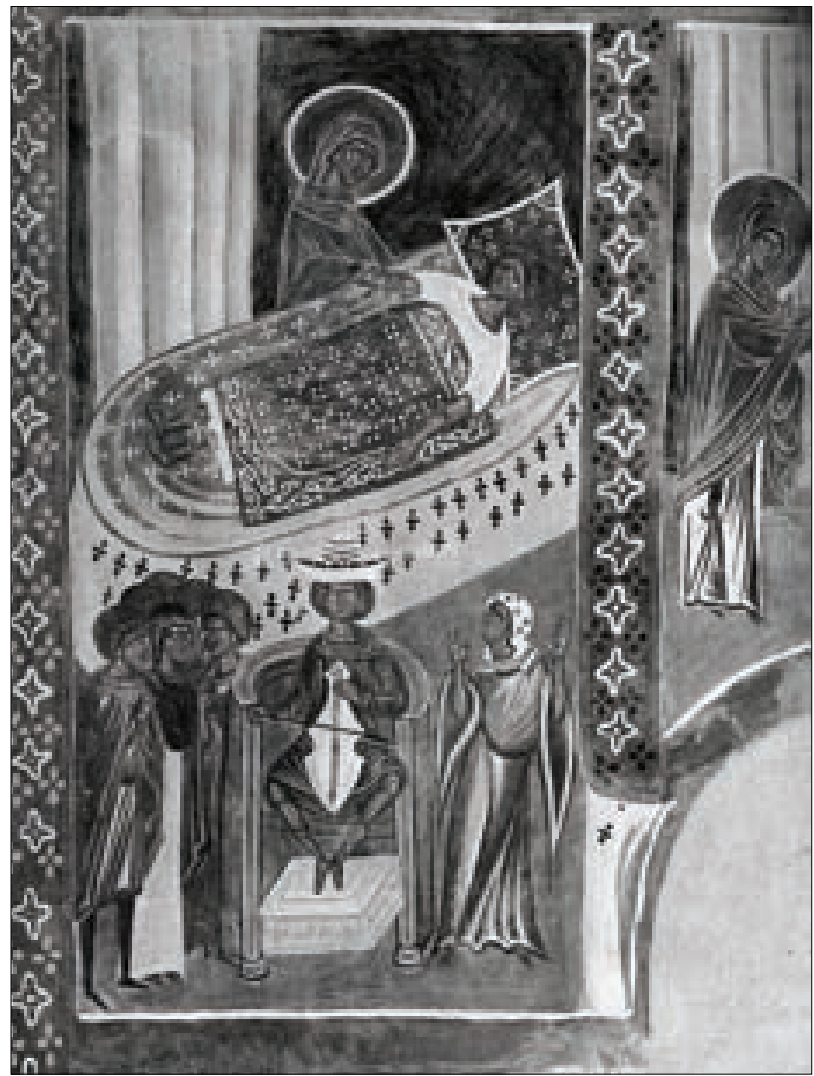

Рис. 4. Фреска западной стены Успенской церкви близ села Мелётово Псковской области (1465 г.) [1, с. 17]

празднества, где вокруг скомороха собрались люди, и справа от него - пляшущая женщина [7, с. 410]. Расположенная композиционно выше вторая часть росписи - это явление Богоматери больной женщине. Д.С. Лихачев полагал, что в первом эпизоде изображен скоморох, своей игрой хуливший Богородицу, а во втором - его исцеление Богоматерью, а не больная женщина, в подтверждение чего он указывает на то, что «одежд лежащей на фреске не видно, а безбородость и безусость лица отличает и скомороха на главном изображении» [8, с. 464].

Композиционное размещение фигуры скомороха построено по типу сюжетов сказания о Царе Давиде, слагающем псалмы. Музыкант является центральной фигурой, он сидит на троне, с левой стороны его окружает группа людей, справа - женщина в движении, руки ее подняты кверху. Возможно, именно это сходство с Царем Давидом породило единственную надпись, проясняющую сюжет фрески. Непосредственно над изображением музыканта прописаны два слова - «Антъ скоморох» ${ }^{7}$. Этот памятник изобразительного искусства относится к двум видам источников - изобразительному и письменному, которые раскрывают друг друга. Таким образом, подпись на

${ }^{7} \mathrm{~B}$ «Лимонисе» имя скомороха записано как «Аннъ». 
данном изображении документально подтверждает, что перед нами скоморох.

Одежды музыканта соответствуют древнерусскому мужскому костюму - длинная рубашка навыпуск, с округлым вырезом, подпоясанная шнуром, и штаны, заправленные в высокие сапоги. Единственная деталь, которая не укладывается в типичный образец крестьянской мужской одежды, - это головной убор. Ю.Н. Дмитриев дает подробное описание: «...головной убор его своеобразен. Это - белая шляпа с большой тульей и с широкими, загнутыми вверх полями. Тулья украшена тремя горизонтальными цветными полосами с орнаментом - нашитыми или раскрашенными - и несколькими поперечными наверху, а сквозь поля шляпы продеты какие-то большие белые кольца» [7, с. 411]. Подобных головных уборов нет в иллюстрациях музыкантов в древнерусском, византийском и западноевропейском искусстве XIII-XVI веков. В русском искусстве XVII-XVIII вв. мы находим приближенные формы шляп у музыкантов [1, с. 32].

Музыкант держит смычковый инструмент перед собой, располагая его между ног, как при игре на виолончели. Корпус небольших размеров имеет ромбовидную форму с выемками по бокам. Шейка и гриф отсутствуют, верхняя дека переходит непосредственно в плоскую головку, которая по своим формам удивительно повторяет очертания корпуса инструмента. Следует отметить, что это первое изображение смычкового инструмента в древнерусском искусстве, где достаточно хорошо сохранилась роспись головки, поэтому можно точно сказать, что это трехструнный инструмент. Расположение колковых отверстий образует треугольник: одно сверху и два отверстия чуть ниже. В нижней части корпуса отчетливо прорисован струнодержатель в виде крюка, что также является новым элементом при воссоздании смычковых инструментов на древнерусских иконографических памятниках.

В правой руке музыканта смычок прямого вида, держит он его «боковым» способом. Изображения смычка с прямой тростью единичны для средневекового искусства, поскольку в этот период преобладает лукообразный смычок. Трость начинает выпрямляться не ранее XVI в., тем не менее из четырех иллюстраций смычковых инструментов в древнерусском искусстве XI-XV вв. две имеют прямой смычок. На фреске Церкви Успения в Мелётово (вторая половина XV в.) смычок в руках музыканта намного длиннее, чем у исполнителя на росписях в Софийском соборе (XI в.), он практически приближен к длине скрипичного смычка. В обоих случаях исполнители на изображениях держат смычок «боковым» способом.

В древнерусских письменных источниках (и духовной, и светской литературы) нет описаний смычка, лишь только упоминания о нем. Иловицкая
Кормчая книга А. Михановича (1262) и сербский Рашский список Кормчей книги (1305) содержат термин «лоучьц» (лучец) для обозначения смычка. Так, в Кормчей книге А. Михановича указано: «Гоудьцъ есть смычькъ иже гоудіть лоучьцемъ» $[10$, c. 866]. Я. Штелин, обрисовывая манеру исполнительства на гудке, отмечает, что смычок его был короткий, и при игре им проводили по всем трем струнам одновременно [4, с. 66]. Живая фольклорная традиция сохранила и другие наименования смычка - погудальце, гудило, гудало и лучок. Возможно, название «лучец» указывает нам на лукообразную форму смычка. Точных сведений относительно внешнего вида древнерусского смычка обнаружить пока не удалось.

Является ли изображение смычка с прямой тростью результатом художественного виденья мастера или же подобные смычки использовались в музыкальной практике? На сегодняшний день мы не имеем данных, которые бы позволили дать однозначный ответ. Возможно, в музыкальной практике Средневековья были случаи употребления смычков с прямой тростью, что нашло отражение в изобразительном искусстве.

Рассматривая инструмент в руках скомороха, мы можем выделить детали, которые характерны для новгородских и псковских средневековых гудков, найденных при археологических раскопках:

- отсутствие грифа с шейкой (корпус инструмента плавно переходит в головку);

- ромбовидная головка (которая весьма схожа с псковской находкой головки гудка ХІІІ в., выполненного из сосны);

- типичное треугольное расположение колковых отверстий на головке;

- три струны;

- струнодержатель в виде крюка, закрепленный в нижней части инструмента.

В то же время ромбовидная форма корпуса с округлыми выемками по бокам совершенно не свойственна гудкам из археологических раскопок северо-запада России. Среди найденных в Новгороде гудков XII-XV вв. и их заготовок у нескольких инструментов почти полностью сохранился корпус, который представляет долбленое корытце грушевидной формы без талии. Если предположить, что мелётовский инструмент является переходным вариантом гудка с ярко выраженной талией на корпусе, то мы должны были бы встретить подобные образцы на миниатюрах последующих веков или в описаниях очевидцев, но мы их не находим.

По мнению В.И. Поветкина, изображение инструмента условно, в нем «равно очевидны помимо русского как византийский, так и западноевропейский смычковые инструменты» [11, с. 151]. Гипотеза о присутствии византийских признаков противоречит тому, что смычковые инструменты Византии 
имели грушевидную форму без талии на корпусе. На наш взгляд, иллюстрация смычкового инструмента на фреске из Мелётово уже не содержит элементов византийского образца, несмотря на то, что композиция основана на византийском литературном источнике.

Скорее, здесь мы видим особенности западноевропейских смычковых инструментов - гитарообразного фиделя. Форма корпуса с талией и плоская головка характерны для данного инструмента. В «Атласе к истории смычковых инструментов» Ю. Рюльмана есть близкого вида безгрифовые фидели [12], в таблице VII. «Die Fidel» инструменты имеют ромбовидную головку и корпус с выраженной талией (см. рис. 5). Однако их отличает от инструмента на Мелётовской фреске горизонтальное игровое положение и количество струн (первый инструмент - четыре струны, а второй - пять).

Образ музыканта на фреске содержит типичные древнерусские черты, а подпись «скоморох» указывает на его происхождение. Автор фрески подробно воссоздает устройство инструмента, которое конструктивно во многом схоже с гудками из археологических раскопок северо-запада России (Псков и Великий Новгород). Можно предположить, что инструмент существовал в музыкальном быту, окружавшем художника - настолько тщательно вырисованы детали инструмента: расположение колковых отверстий, наличие струнодержателя в виде крюка и положение пальцев левой руки около головки. Как отмечено выше, впервые на древнерусской миниатюре запечатлен музыкант, который держит инструмент в вертикальном игровом положении. Впоследствии именно эта манера игры становится преобладающей при изображении музыкантов-исполнителей на смычковых инструментах в древнерусском искусстве. И все же, несмотря на все обозначенные национальные особенности, мы не можем однозначно определить инструмент на Мелётовской фреске как подлинно древнерусский, поскольку подобных образцов нет ни в археологических материалах, ни в древнерусских изобразительных памятниках, ни в письменных источниках последующих веков. Смычковый инструмент Мелётовской фрески остается единственным в своем роде.

Этим изображением завершается первый период в иллюстрации смычковых инструментов в древнерусском искусстве. Мы определяем его временные рамки с XI по XV век. Специфической особенностью данного периода является разрозненность, единичность изображений смычковых инструментов и преобладающее влияние византийской художественной системы. Исследование смычковых инструментов древнерусского искусства XI-XV вв. осложняется почти полным отсутствием изобразительного материала. До нашего времени сохранилось лишь не-
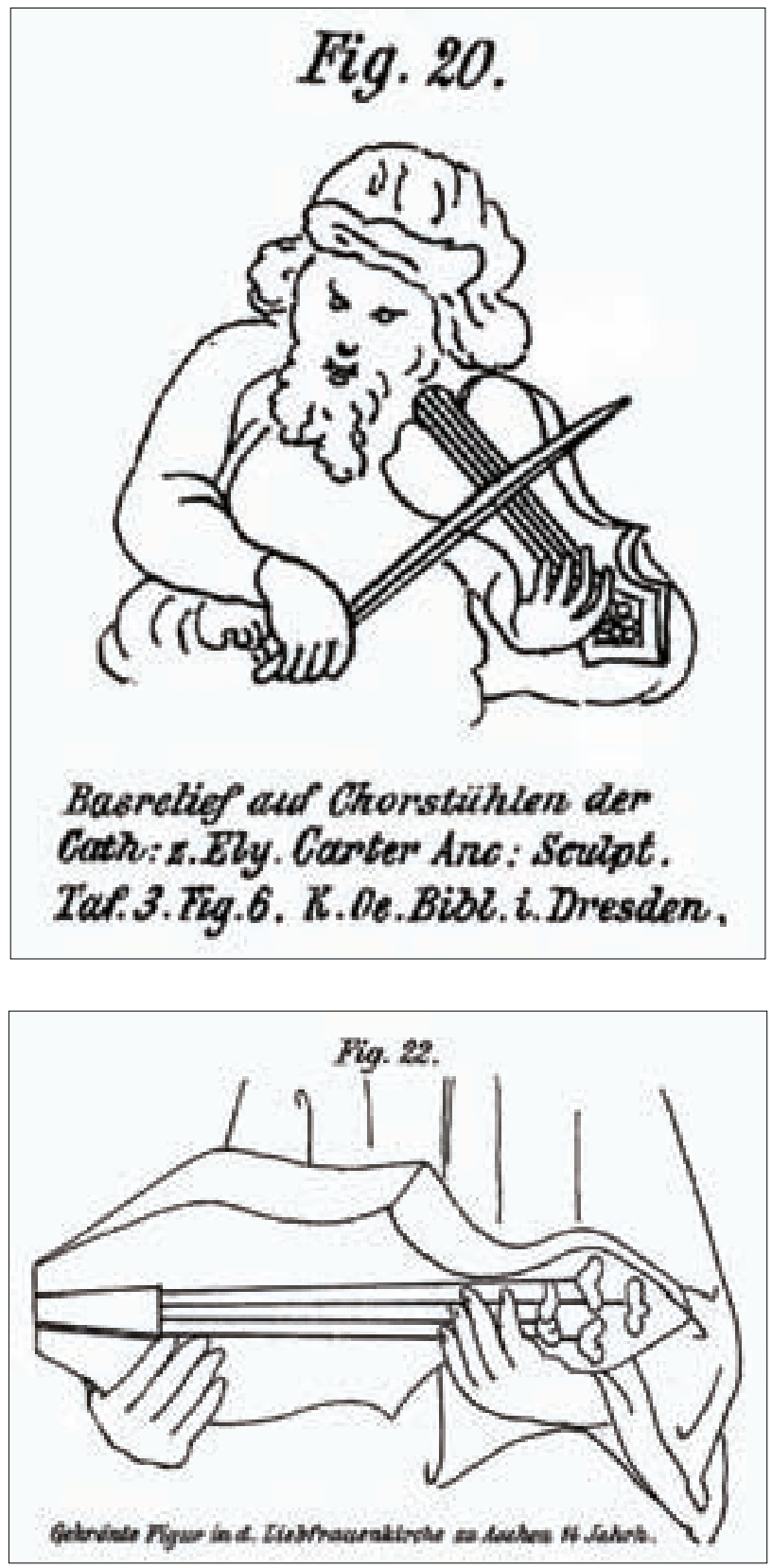

Рис. 5. Западноевропейские фидеели XII в. (Fig. 20) и XIV в. (Fig. 22) (по Атласу Ю. Рюльмана) [12]

сколько древнерусских иконографических памятников, воссоздающих образ смычковых инструментов: фреска Софийского собора (Киев, ХІ в.), миниатюра Новгородской (Хлудовской) Псалтири (Новгород, конец XIII в.), миниатюра Следованной Псалтири (Вологодская обл., конец XV в.) и фреска Церкви Успения в Мелётово (Псковская область, вторая половина XV в.).

В целостной системе древнерусской культуры византийская иконографическая схема изображения была принята не только через документацию и некоторый визуальный образец, но и через непосредственное живое внедрение традиции от ма- 
стера к ученику. Византийские мастера являются первыми создателями древнерусских фресок, миниатюр, но они и учителя, открывшие красоту богослужения. Перенимая византийский опыт, они творчески его переосмысливают, вырабатывая свои национальные специфические формы выражения.

В то же время не менее значительным оказывается западноевропейское влияние, которое наиболее ярко проявлялось при изображении музыкальных инструментов на древнерусских миниатюрах. Порой мы видим на одной иллюстрации рядом византийские и западноевропейские инструменты (например, миниатюра Новгородской (Хлудовской) Псалтири, конец XIII в.).

C XV в. в изображении смычковых инструментов и самого облика музыкантов начинают проявляться национальные черты. Впервые на древнерусских миниатюрах и фресках именно в этот период появляются подписи, поясняющие, что на них изображены народные музыканты. Меняется воссоздание игрового положения тела исполнителя. Если в XI-XIII вв. музыканты со смычковыми инструментами сидят, сложив ноги по-восточному в позе лотоса, то в XV в. мы уже наблюдаем, что они стоят или сидят с расположением инструмента перед собой, что соответствует русской народной исполнительской манере. Ряд конструктивных особенностей изображенных инструментов сближает их с гудками XII-XV вв. Новгородской археологической экспедиции (форма корпуса, головки, отсутствие продолженного грифа, наличие трех струн и лукообразный смычок). C XV в. происходит постепенное введение в древнерусские иконографические памятники некоторых элементов, присущих реальным смычковым инструментам и исполнителям Древней Руси.

В.И. Поветкин полагал, что «гипотеза об отождествлении средневековыми художниками библейских музыкальных инструментов с национальными... не соответствует ситуации на Руси. Часть наших памятников, которая создавалась под влиянием церкви, слишком далека от состояния источника, способного непосредственно характеризовать облик древнерусских музыкальных инструментов» [11, с. 156]. На наш взгляд, высказывание В.И. Поветкина верно относительно древнерусских иллюстраций XI-XIV вв., которые были созданы в соответствии с византийским стилем и со вставками западноевропейских элементов в изображении музыкальных инструментов. Древнерусские миниатюры и фрески XV в. являются ценным историческим источником, позволяющим дополнить наши представления о смычковом инструментарии, спо- собах игры на них и внешнем облике музыканта-исполнителя Древней Руси. Изображения смычковых инструментов на древнерусских иконографических памятниках XV в. представляют некоторый переходный образец, содержащий признаки византийского и западноевропейского инструментария, но с уже проявляющимися специфическими национальными древнерусскими чертами.

\section{Список источников}

1. Гинзбург Л.С. Народные истоки виолончельного искусства в России // Гинзбург Л.С. История виолончельного искусства. Москва : Музгиз, 1957. Т. 2. С. 9-63.

2. Гордиенко Э.А., Семячко С.А., Шибаев М.А. Миниатюра и текст: из истории рукописной Следованной псалтири XV-XVI вв. из РНБ. Санкт-Петербург : Пушкинский дом, 2010. 268 с.

3. Каминская Н.М. История костюма. Москва : Легкая индустрия, 1977. 128 с.

4. Штелин Я. Музыка и балет в России XVIII века / пер. Б.И. Загурского. Ленинград : Муз. издат., 1935. 191с.

5. Munrow D. Instruments of the Middle Ages and Renaissance. Oxford : Oxford Univ. Press, Music Dept., $1976.95 \mathrm{p}$.

6. Богушевский Н.К. Церковь Успения в Мелётове // Псковские губернские ведомости. 1876. № 18. С. 128.

7. Дмитриев Ю.Н. Мелётовские фрески и их значение для истории древнерусской литературы // Труды Отдела древнерусской литературы / Академия наук СССР. Институт русской литературы (Пушкинский Дом) ; ред. В.П. Адрианова-Перетц. Москва ; Ленинград : Изд-во Академии наук СССР, 1951. Т. 8. С. $403-412$.

8. Лихачев Д.С. Древнейшее русское изображение скомороха и его значение для истории скоморошества // Проблемы сравнительной филологии : сб. ст. к 70-летию чл.-кор. АН СССР В.М. Жирмунского. Москва : Наука, 1964. С. 462-466.

9. Бобров А.Г. Литературный источник Мелётовской фрески / Т Труды Отдела древнерусской литературы / Академия наук СССР. Институт русской литературы (Пушкинский Дом) ; отв. ред. Н.В. Понырко. СанктПетербург : Наука, 2014. Т. 62. С. 485-499.

10. Miklosich F. von. Lexicon Palaeoslovenico-GraecoLatinum. Neudruck der Ausgabe Wien, 1862-1865. Aalen : Scientia Verlag, 1977. 1171 p.

11. Поветкин В.И. «Русский» изобразительный канон на музыкальные инструменты // Памятники культуры. Новые открытия : ежегодник 1989. Москва : Наука, 1990. C. $136-159$.

12. Rühlmann J. Atlaszur Geschichteder Bogeninstrumente. Braunschweig : Druck und Verlag von Friedrich Vieweg und Sohn, 1882. $8 \mathrm{~S}$. 


\section{Old Russian Iconographic Monuments of the 15th Century as a Source of Information on Bowed Instruments}

\author{
Alexandra V. Ustyugova \\ M. Gorky Krasnoyarsk Pedagogical College No. 1, 106, \\ Uritskogo Str., Krasnoyarsk, 660049, Russia \\ E-mail: uav80@mail.ru
}

\begin{abstract}
Studying Old Russian art sources gives valuable historical and everyday material that allows us to fill and clarify our ideas about musical instruments: the features of their design and functioning. Frescoes and miniatures from manuscripts are of particular importance among the extant information on Old Russian bowed instruments. The article deals with the images of bowed instruments on the fresco "Ant Skomorokh" of the western wall of the Assumption Church near the village of Melyotovo in the Pskov region (1465) and the miniature "King David Speaks with the Singers" from the first part of the Sacred Psalter (1470-1480). The iconographic sources under examination contain not only images of bowed instruments, but also inscriptions, which increases their importance for the study of Old Russian instrumental culture.

For the first time, the article attempts to complexly analyze bowed instruments in the Old Russian art of the 15th century, comparing them with medieval Western European and Byzantine illustrations and with Old Russian written and archaeological materials.

The comparative-typological and historical approaches form the methodological basis of the study. They allow identifying and relating the main types of medieval bowed instruments, their similarity in form and performing techniques. As a result of the comparative-typological analysis of the Old Russian iconographic monuments of the 15th century, it is concluded that the images of bowed instruments represent some transitional pattern - they still demonstrate links with the Byzantine canon, contain signs of Western European instruments, but already incorporate specific national Old Russian features. In the 15th century, some inscriptions began to appear on Old Russian miniatures and frescoes, explaining that there were folk musicians on them. In the same period, the vertical playing arrangement of the instrument was introduced for the first time in the Old Russian art, which corresponded to the Russian tradition of performing on bowed instruments. A number of design features unite these instruments with the gudoks of the 12th-15th centuries from the Novgorod archaeological excavations (the shape of hull, lack of a prolonged neck, presence of three strings and the form of bow).
\end{abstract}

Key words: Old Russian pictorial art, Russian instrumental music of the 15th century, bowed instruments, gudok.
Citation: Ustyugova A.V. Old Russian Iconographic Monuments of the 15th Century as a Source of Information on Bowed Instruments, Observatory of Culture, 2018, vol. 15, no. 1, pp. 58-65. DOI: $10.25281 / 2072-$ 3156-2018-15-1-58-65.

\section{References}

1. Ginzburg L.S. Folk Sources of the Cello Art in Russia, Istoriya violonchel'nogo iskusstva [The History of Cello Art]. Moscow, Muzgiz Publ., 1957, vol. 2, pp. 9-63 (in Russ.).

2. Gordienko E.A., Semyachko S.A., Shibaev M.A. Miniatyura i tekst: iz istorii rukopisnoi Sledovannoi psaltiri XV$X V I$ vv. iz RNB [Miniature and Text: From the History of the Handwritten Sacred Psalter of the 15th-16th Centuries from the National Library of Russia]. St. Petersburg, Pushkinskii Dom Publ., 2010, 268 p.

3. Kaminskaya N.M. Istoriya kostyuma [The History of Costume]. Moscow, Legkaya Industriya Publ., 1977, 128 p.

4. Shtelin Ya. Muzyka i balet v Rossii XVIII veka [Music and Ballet in Russia in the 18th Century]. Leningrad, Muzykal'noe Publ., 1935, $191 \mathrm{p}$.

5. Munrow D. Instruments of the Middle Ages and Renaissance. Oxford, Oxford University Press Publ., 1976, 95 p.

6. Bogushevsky N.K. The Assumption Church in Melyotovo, Pskovskie gubernskie vedomosti [Pskov Provincial News], 1876, no. 18, pp. 128 (in Russ.).

7. Dmitriev Yu.N. The Melyotovo Frescoes and their Significance for the History of Old Russian Literature, Trudy Otdela drevnerusskoi literatury [Proceedings of the Department of Old Russian Literature]. Moscow, Leningrad, Akademii Nauk SSSR Publ., 1951, vol. 8, pp. 403-412 (in Russ.).

8. Likhachev D.S. The Oldest Russian Picture of Skomorokh and its Significance for the History of Skomorokhs, Problemy sravnitel'noi filologii: sb. st. $k$ 70-letiyu chl.kor. AN SSSR V.M. Zhirmunskogo [Problems of Comparative Philology: collected articles to the 70th anniversary of V.M. Zhirmunsky, a corresponding member of the Academy of Sciences of the USSR]. Moscow, Nauka Publ., 1964, pp. 462-466 (in Russ.).

9. Bobrov A.G. A Literary Source of the Melyotovo Frescoes, Trudy Otdela drevnerusskoi literatury [Proceedings of the Department of Old Russian Literature]. St. Petersburg, Nauka Publ., 2014, vol. 62, pp. 485-499 (in Russ.).

10. Miklosich F. von. Lexicon Palaeoslovenico-Graeco-Latinum. Neudruck der Ausgabe Wien, 1862-1865. Aalen, Scientia Publ., 1977, 1171 p.

11. Povetkin V.I. The "Russian" Pictorial Canon for Musical Instruments, Pamyatniki kul'tury. Novye otkrytiya: ezhegodnik 1989 [Monuments of Culture. New Discoveries: Yearbook 1989]. Moscow, Nauka Publ., 1990, pp. 136159 (in Russ.).

12. Rühlmann J. Atlaszur Geschichteder Bogeninstrumente. Braunschweig, Friedrich Vieweg und Sohn Publ., 1882, 8 p. 